\title{
Sheehan's syndrome with pancytopenia: a case report and review of the literature
}

\author{
Mnif Fatma, Elleuch Mouna*, Rekik Nabila, Mnif Mouna, Charfi Nadia and Abid Mohamed
}

\begin{abstract}
Introduction: Sheehan's syndrome is defined by varying degrees of anterior pituitary deficiency due to postpartum ischemic necrosis of the pituitary gland after massive bleeding. It is a rare disorder in western countries and even in Tunisia. Hematologic abnormalities such as normochromic anemia have been reported in these patients. However, pancytopenia is rarely observed.

Case presentation: We describe the case of a 48-year-old Tunisian woman with features of hypopituitarism. Laboratory tests showed pancytopenia that was completely reversed after adequate hormone replacement.

Conclusion: Clinicians should consider the possibility of hypopituitarism as a cause of pancytopenia. This is an original case report that is of interest to hematologists, who should be aware of Sheehan's syndrome as a treatable etiology of pancytopenia for women.
\end{abstract}

\section{Introduction}

Sheehan's syndrome is characterized by varying degrees of anterior pituitary dysfunction due to postpartum ischemic necrosis of the pituitary gland after massive bleeding. The most frequent hematologic finding is anemia. Pancytopenia is rarely observed in patients with Sheehan's syndrome. Only seven cases have been reported up to now.

\section{Case presentation}

A 48-year-old Tunisian woman was urgently sent to our intensive care department with confusion, vomiting, abdominal pain and diarrhea. A low blood pressure was observed $(95 / 65 \mathrm{mmHg})$. An initial laboratory test showed hyponatremia at $119 \mathrm{mmol} / \mathrm{L}$ and pancytopenia. Her leukocyte count was $3 \times 10^{9} / \mathrm{L}$ with a neutrophil count of $1.8 \times 10^{9} / \mathrm{L}$. Her hemoglobin level was $7.9 \mathrm{~g} / \mathrm{dL}$ with mean corpuscular volume at $87.7 \mathrm{fL}$, mean corpuscular hemoglobin at 32pg and mean corpuscular hemoglobin concentration at $30 \mathrm{~g} / \mathrm{dL}$. Her platelet count was at $92 \times 10^{9} / \mathrm{L}$. Her serum ferritin level was normal at $7.29 \mathrm{ng} / \mathrm{mL}$. A bone marrow biopsy revealed hypocellular marrow with hypocellular cell trails. A detailed interview revealed that she had excessive bleeding in the course of her first delivery at the age of 22 years. In addition, lactation failed and

\footnotetext{
* Correspondence: elleuch_mouna@yahoo.fr

Endocrinology Department, Hedi Chaker Hospital, (3029) Sfax, Tunisia
}

menstruation did not resume. She also complained about generalized weakness. A physical examination showed pallor and doughy skin. Her breast tissue was normal but the areolae were depigmented. She had no pubic or axillary hair. Pituitary hormone studies were compatible with a status of primary pituitary insufficiency (Table 1 ). In fact follicle-stimulating hormone was at $3.6 \mathrm{mIU} / \mathrm{mL}$, luteinizing hormone was at $0.6 \mathrm{mIU} / \mathrm{mL}$ and estradiol less than $9 \mathrm{pg} / \mathrm{mL}$. Free thyroxine was low at $1.8 \mathrm{pmol} / \mathrm{L}$ with an inadequate level of thyroid-stimulating hormone at $3.9 \mu \mathrm{U} / \mathrm{L}$. Her basal serum cortisol (measured at 8 a.m.) was $20 \mathrm{ng} / \mathrm{mL}$, cortisol (measured at 4 p.m.) was at $19.5 \mathrm{ng} / \mathrm{mL}$ and cortisol (measured at 11 p.m.) was $18.1 \mathrm{ng} / \mathrm{mL}$. After a synacthen stimulation test, cortisol was at $36 \mathrm{ng} / \mathrm{mL}$. Her prolactin level was $2.8 \mu \mathrm{g} / \mathrm{L}$. The diagnosis of Sheehan's syndrome was established and pituitary magnetic resonance images demonstrated an empty sella. She received replacement therapy with L-thyroxine $100 \mu \mathrm{g} /$ day and hydrocortisone $20 \mathrm{mg}$ /day.

Our patient was followed for six weeks after which a complete hematological recovery was noted, with a eucortisolemic and euthyroid state. In fact, the hematologic abnormality had dramatically improved. Her leukocyte count was $6.2 \times 10^{9} / \mathrm{L}$, her hemoglobin level was $10 \mathrm{~g} / \mathrm{dL}$ and her platelet count was $219 \times 10^{9} / \mathrm{L}$, all within the normal range. 
Table 1 Hematological anomalies in previously published cases and our patient [5]

\begin{tabular}{|c|c|c|c|c|c|c|c|c|}
\hline Case & Ref & $\begin{array}{l}\mathrm{Hb} \\
\mathrm{g} / \mathrm{dL}\end{array}$ & $\begin{array}{l}\text { TLC } \\
\times 10^{3} / \mu \mathrm{L}\end{array}$ & $\begin{array}{l}\mathrm{MCV} \\
\mathrm{fL}\end{array}$ & $\begin{array}{l}\mathrm{MCH} \\
\mathrm{pg}\end{array}$ & $\begin{array}{l}\text { MCHC } \\
\mathrm{g} / \mathrm{dL}\end{array}$ & $\begin{array}{l}\mathrm{PLT} \\
\times 10^{3} / \mu \mathrm{L}\end{array}$ & $\begin{array}{l}\text { Reticulocyte } \\
\%\end{array}$ \\
\hline 1 & [6] & 9 & 3.4 & 87 & 31 & 36 & 71 & 0.4 \\
\hline 2 & [7] & 6.5 & 2.3 & 85 & 33 & 35 & 96 & 0.2 \\
\hline 3 & [4] & 7.5 & 3.42 & 96.9 & 32.8 & 33.8 & 70 & 0.9 \\
\hline 4 & [8] & 9 & 2.3 & - & - & - & 90 & 0.3 \\
\hline 5 & [5] & 9.2 & 3.2 & 94.2 & 30.7 & 32.4 & 64 & 0.3 \\
\hline 6 & [5] & 10.6 & 3.4 & 82.2 & 26.4 & 32.1 & 74 & 0.5 \\
\hline 7 & [5] & 9.8 & 3.2 & 94.8 & 33.1 & 31.6 & 42 & 0.2 \\
\hline 8 & Present case & 7.9 & 3 & 87.7 & 32 & 30 & 92 & \\
\hline
\end{tabular}

Hb: hemoglobin; TLC: total leucocyte count; PLT: platelets; MCV: mean corpuscular volume; MCH: mean corpuscular hemoglobin; MCHC: mean corpuscular hemoglobin concentration.

\section{Discussion}

The diagnosis of Sheehan's syndrome is determined by the patient's history and physical examination, and confirmed by laboratory tests (hormone levels and hormone stimulation tests which prove anterior pituitary failure). Laboratory tests can reveal many other anomalies such as hyponatremia. This is the most common electrolyte imbalance, occurring in $33 \%$ to $69 \%$ of cases $[1,2]$. Cortisol deficiency, hypothyroidism and volume depletion are the main causes of hyponatremia. It also seems that Sheehan's syndrome has hematological consequences, to which little attention is paid because of their rarity. Anemia is well recognized as a feature of hypopituitarism. Gokalp et al. have recently reported hematological abnormalities in 65 patients with Sheehan's syndrome, $80 \%$ of whom presented with anemia, compared with $25 \%$ of controls [3]. Many hormonal deficiencies, such as hypothyroidism, adrenal insufficiency and gonadal hormonal deficiency, can explain normochromic anemia in hypopituitarism [4]. On the other hand, it can be the result of a physiologic adjustment to lower oxygen requirement, as pituitary hormones modulate the production of erythropoietin in the kidney [5]. The low erythropoietin levels found in these patients support this argument. However, within the framework of hematologic disorders, pancytopenia is rarely observed in patients affected with Sheehan's syndrome.

A literature review revealed the rarity of this disorder. The first case was reported by Ferrari et al. in 1975 [6]. Only seven cases have been reported up to now (Table 1 and Table 2) [5]. The mean age of these women was 41.1 years (range: 22 to 57 years). The mean time between the hemorrhagic accident and diagnosis was at 11.1 years (range: two to 27 years) $[5,7,8]$. Hematologic disorders were behind the discovery of Sheehan's syndrome in four cases. Hormonal investigations confirmed thyroid, adrenal and gonadal deficiency in all cases. A bone marrow biopsy was carried out for all patients showing hypocellularity and decreased hemopoiesis, erythropoiesis and granulopoiesis. Pancytopenia as a result of an anterior hormone deficiency has not been clearly investigated. It is a consequence of the loss of effect of pituitary hormones on metabolic reactions to hematopoiesis, which is related to hypopituitarism [4,5]. How the anterior pituitary insufficiency can lead to complete marrow aplasia has not been clear until now. Treatment with thyroxine and glucocorticoides led to full hematological recovery in all published cases after a eucortisolemic and euthyroid

Table 2 Hormonal results of all reported patients [5]

\begin{tabular}{|c|c|c|c|c|c|c|c|c|}
\hline & Case 1 & Case 2 & Case 3 & Case 4 & Case 5 & Case 6 & Case 7 & Our patient \\
\hline $\mathrm{T} 4 \mu \mathrm{g} / \mathrm{dL}$ & 1 & 0.9 & 0.23 & 0.43 & 1.8 & 1 & $<1$ & 1.8 \\
\hline $\mathrm{TSH} \mu \mathrm{U} / \mathrm{mL}$ & $?$ & 0.34 & 1.9 & 1.4 & 0.39 & 2.9 & 1.49 & 3.9 \\
\hline$\overline{F S H ~ I U / L ~}$ & 0.3 & 1.6 & 1 & 0.58 & 2.9 & 1.07 & 7.43 & 3.6 \\
\hline $\mathrm{LH} I \mathrm{U} / \mathrm{L}$ & 0.8 & 1.1 & 1.6 & 0.18 & 0.74 & 1.07 & 0.75 & 0.6 \\
\hline $\mathrm{PRL} \mu \mathrm{g} / \mathrm{L}$ & - & - & - & - & 2.8 & 1 & 1.9 & 2.8 \\
\hline Cortisol $\mu \mathrm{g} / \mathrm{dL}$ & 4 & - & 0.7 & $<1$ & 5.8 & $<1$ & 6.6 & 20 \\
\hline $\mathrm{GH} \mu \mathrm{g} / \mathrm{L}$ & 0.3 & 0.08 & - & $<0.05$ & $<0.25$ & $<0.25$ & 0.24 & - \\
\hline$\overline{\mathrm{ACTH}} \mathrm{ng} / \mathrm{mL}$ & - & $<1$ & 12 & $<10$ & - & - & - & - \\
\hline
\end{tabular}

ACTH: adrenocorticotropic hormone; FSH: follicle stimulating hormone; GH: growth hormone; LH: luteinizing hormone; PRL: prolactin; TSH: thyroid stimulating hormone; T4: thyroxine. 
state was attained after a follow up of 20 days to four months. For our patient, hematological recovery was obtained after six weeks.

\section{Conclusion}

Pancytopenia is a rare appearance of a hormonal abnormality; clinicians should consider the possibility of hypopituitarism as a cause of pancytopenia and indicate a series of hormonal examinations. Multiple anterior pituitary hormone deficiencies in Sheehan's syndrome can be responsible for pancytopenia. A simple replacement therapy with thyroid and cortisol hormones results in complete recovery. So, hematologists need to be aware of Sheehan's syndrome as a treatable etiology of pancytopenia in women.

\section{Patient's perspective}

Since the postpartum I suffered from fatigue, pallor, anemia and amenorrhea. Recently I presented with vomiting and diarrhea. Biological findings showed pancytopenia and hypopituitarism. After starting hormone replacement treatment, I felt better. I prefer to remain anonymous.

\section{Consent}

Written informed consent was obtained from the patient for publication of this manuscript and any accompanying images. A copy of the written consent is available for review by the Editor-in-Chief of this journal.

\section{Acknowledgements}

For the reprint of the Table 1 and Table 2, permission has been given, after the authors have accepted the terms and conditions on Springer's website.

\section{Authors' contributions}

MF analyzed and interpreted the patient data regarding the endocrinological disease and was a major contributor in writing the manuscript. EM analyzed and interpreted the patient data regarding the endocrinological disease and was a major contributor in writing the manuscript. RN interpreted the patient data regarding the hematological disease. MM performed the bone marrow biopsy. CN interpreted the patient data regarding the hematological disease. AM analyzed and interpreted the patient data regarding the endocrinological disease. All authors have read and approved the final manuscript.

\section{Competing interests}

The authors declare that they have no competing interests.

Received: 10 November 2010 Accepted: 3 October 2011 Published: 3 October 2011

\section{References}

1. Anfuso S, Patrelli TS, Soncini E, Chiodera P, Fadda GM, Nardelli GB: A case report of Sheehan's syndrome with acute onset, hyponatremia and severe anemia. Acta Biomed 2009, 80(1):73-76.

2. Huang YY, Ting MK, Hsu BR, Tsai JS: Demonstration of reserved anterior pituitary function among patients with amenorrhea after postpartum hemorrhage. Gynecol Endocrinol 2000, 14(2):99-104.
3. Gokalp D, Tuzcu A, Bahceci M, Arikan S, Bahceci S, Pasa S: Sheehan's syndrome as a rare cause of anemia secondary to hypopituitarism. Ann Hematol 2009, 88(5):405-410.

4. Kim DY, Kim JH, Park YJ, Jung KH, Chung HS, Shin S, Yun SS, Park S, Kim BK: Case of complete recovery of pancytopenia after treatment of hypopituitarism. Ann Hematol 2004, 83(5):309-312.

5. Laway BA, Bhat JR, Mir SA, Khan RS, Lone MI, Zargar AH: Sheehan's syndrome with pancytopenia-complete recovery after hormone replacement (case series with review). Ann Hematol 2010, 89(3):305-308

6. Ferrari E, Ascari E, Bossolo PA, Barosi G: Sheehan's syndrome with complete bone marrow aplasia: long-term results of substitution therapy with hormones. Br J Haematol 1976, 33(4):575-582.

7. Ozdogan M, Yazicioglu G, Karadogan I, Cevikol C, Karayalcin U, Undar L: Sheehan's syndrome associated with pancytopenia due to marrow aplasia: full recovery with hormone replacement therapy. Int J Clin Pract 2004, 58(5):533-535.

8. Akoz AG, Atmaca H, Ustundag Y, Ozdamar SO: An unusual case of pancytopenia associated with Sheehan's syndrome. Ann Hematol 2007, 86(4):307-308.

doi:10.1186/1752-1947-5-490

Cite this article as: Fatma et al.: Sheehan's syndrome with pancytopenia: a case report and review of the literature. Journal of Medical Case Reports 2011 5:490.

\section{Submit your next manuscript to BioMed Central and take full advantage of:}

- Convenient online submission

- Thorough peer review

- No space constraints or color figure charges

- Immediate publication on acceptance

- Inclusion in PubMed, CAS, Scopus and Google Scholar

- Research which is freely available for redistribution 